\title{
Russian-Iranian Strategic Partnership in Syria: Converging Interests but Diverging Goals
}

\author{
Tan Tan*, Mariia German \\ School of Government, Shanghai University of Political Science and Law, Shanghai, China \\ Email: *tantan@shupl.edu.cn
}

How to cite this paper: Tan, T., \& German, M. (2022). Russian-Iranian Strategic Partnership in Syria: Converging Interests but Diverging Goals. Open Journal of Political Science, 12, 1-13.

https://doi.org/10.4236/ojps.2022.121001

Received: November 26, 2021

Accepted: December 27, 2021

Published: December 30, 2021

Copyright $\odot 2022$ by author(s) and Scientific Research Publishing Inc. This work is licensed under the Creative Commons Attribution International License (CC BY 4.0).

http://creativecommons.org/licenses/by/4.0/ (c) (i) Open Access

\begin{abstract}
Strategic partnership is an evolving phenomenon, and there has been no consensus on its definition. But the academic endeavors by now manifest some degrees of congruence on the constitutive features of strategic partnership. This study first generalizes the constitutive features of strategic partnership. Then through the lens of these constitutive features, the relationship of Russia and Iran is examined. They have some converging interests in Syria: the common perception of a Western challenge, a high degree of military-security cooperation, similar economic motivations for their interventions in support of Assad regime, and the geopolitical importance of Syria to both countries. However, they have diverging goals in Syria too: serious ideological differences, the instrumentality of Syria in Russia's strategy, rivalry for influence, divergent policies to Israel, and potential competitors as energy suppliers. Thus, in the framework of the Syrian crisis, Russo-Iranian relations are difficult to characterize as typical strategic partnership. Their relationship is "tactical rather than strategic" and their interactions are "pragmatic rather than systematic".
\end{abstract}

\section{Keywords}

Russia, Iran, Strategic Partnership, Syrian Crisis, The Middle East

\section{Introduction}

From the beginning of Syrian crisis, the positions of Russia and Iran coincided: both countries supported the preservation of the Syrian Arab Republic's territorial integrity and they have some common economic and political interests in Syria. Due to external intervention, internal crisis in Syria rapidly transformed into an international one, what called into question the existence of Syrian State. In this regard, Russia and Iran's role turned out to be very important to Syria, 
and the results of their joint impact on the development of Syrian crisis settlement are positive. The split of Syria and the overthrowing of Bashar Al-Assad were avoided. It is a fact that Russo-Iranian relations have never been so close in Syria. As stakeholders, their relationship is very important both to the outcome of the Syrian peace process and to the achievement of their respective geopolitical strategies. However, there are disaccords between Russia and Iran in the topical issue of post-conflict settlement and the key role in peaceful regulations. Is the cooperation between Russia and Iran in Syria strategic or tactical, in other words, is it a long-term interaction or conjunctural dialogue? So, it is necessary to clarify their relationship or "strategic partnership".

\section{The Constitutive Features of Strategic Partnership}

Strategic partnerships are evolving phenomena in contemporary international relations, and there is no consensus on the definition of "strategic partnership" in the academic circle. But under the general term of "strategic partnership" in political science and IR theory, scholars have generalized an satisfactory one within the "mosaic of strategic partnership manifestations" (Czechowska, Tyushka, Domachowska, Gawron-Tabor, \& Piechowiak-Lamparska, 2019: p. 18). Strategic partnership could be defined as "a bilateral relation, characterized by simultaneously the institutional flexibility and exceptional closeness, and intensiveness of relations between subjects that keep their legal sovereignty, that are convinced about the integrity of their strategic goals, and therefore decide to cooperate on the long-term basis to implement them." (Czechowska, 2013)

In contrast to the relationship of allies or adversaries, strategic partnership tends "to be informal in nature and entail low commitment costs, rather than being explicitly formalized in a specific alliance treaty that binds the participants to rigid courses of action" (Wilkins, 2008: p. 361). Generally speaking, strategic partnership contains several constitutive features that include: 1) "similar interests among partners, and, ideally, their convergence"; 2) "a high degree of convergence of views and approaches to key issues of regional and/or global politics"; 3) "the willingness to reconcile one's own interests with the interests of the strategic partner or the willingness to make decisions in support of the partner on the international stage, even if such actions are not necessarily beneficial for one's own good"; 4) "common challenges and threats, and the determination to work together in order to overcome them"; 5) "a mechanism for implementing the strategic partnership", or "the willingness and potential to create such" (Czechowska, Tyushka, Domachowska, Gawron-Tabor, \& Piechowiak-Lamparska, 2019: pp. 23-24).

Nadkarni (2010) developed the constitutive features of strategic partnership that consist of "several common elements forging links between countries" of a strategic partnership. Among them, including: 1) they (the partner countries) are formalized in multiple written declarations, statements or agreements that "outline clear objectives and attempt to build upon and deepen multifaceted 
ties"; 2) they create formal institutional links at various levels generating "multiple interactive channels" of communications and set up a mechanism for "summit meetings" between top leaders with "more frequent meetings at the sub-ministerial and bureaucratic level where officials explore common interests or concerns"; 3) they seek to establish "a stronger economic relationship"; 4) they attempt to foster "greater awareness of each other's culture through youth exchanges and cultural fairs" (Nadkarni, 2010: pp. 48-49).

Holslag (2011) classified five main features of strategic partnership, including the partners' "identified common interests and expectations", the quality of the relationship being "formulated for the long term", the relations "need to be multidimensional and operationalized in the economic, political and military areas of interest", "have a global range", as well as "the incentives should be of such a nature that they cannot be achieved without partnership and serve to distinguish it from other relationships" (Holslag, 2011: p. 295).

Though distinct in their perspectives, these academic endeavors "manifest some modest degree of congruence". The most frequently posited constitutive features of strategic partnerships are: "formal institutional links at multiple levels, regular and multi-leveled contacts, shared interests and converging strategic goals, mutual loyalty and commitment, as well as the long-term design and functioning of the relationship". And the second-order variables identified include: "the formal design of the partnership; a greater mutual understanding, respect and trust; actors" converging views on international and regional issues and the system as such; their closer interaction in security affairs and the economic area'; and "shared (not necessarily common or identical) values and norms are said to cement strategic relationships" (Czechowska, Tyushka, Domachowska, Gawron-Tabor, \& Piechowiak-Lamparska, 2019: p. 24).

In order to give a reply to the question that whether the relationship between Russia and Iran in Syria is strategic, it is necessary to analyze their relationship through the lens of the constitutive features of strategic partnership. Some of the features could be easily recognized, but others might be difficult to discern, and still some features of opposite traits has been obvious. All these make their relationship "tactical rather than strategic" and their interactions "pragmatic rather than systematic" (Therme, 2018).

\section{The Converging Interests of Russia and Iran in Syria}

The vectors of development of the entire complex of relations between Russia and Iran are set by constant contacts at the highest levels of interactions between the foreign ministers and parliamentary ties. The "Treaty on the Basis of Relations and Principles of Cooperation between the Russian Federation and the Islamic Republic of Iran" that signed in December 2001 and entered into force in April 2002 is the legal basis of Russian-Iranian relations. The Russian-Iranian strategic partnership is based on the coincidence or proximity of both countries' positions on the global and regional agenda issues. Both countries are interested 
in the construction of a multi-polar world order, strengthening the role of the $\mathrm{UN}$ in international affairs, ensuring regional security, countering the influence of military and political presence of the US and its allies, and advocating the peace process in Syria. During the meeting in Moscow in August 2015, Iran and Russia's Foreign Ministers confirmed the statements that both countries have similar approaches to the stabilization of the situation in the Middle East, the implementation of which will make it possible to more effectively coordinate the efforts of the parties in order to promote the settlement of conflicts in Iraq, Syria and Yemen, as well as to strengthen the joint fight against the terrorist threat emanating from the ISIS and other extremist groups (Lavrov, 2015).

The Secretary of Iran's Supreme National Security Council (SNSC) Ali Shamkhani in an interview with the fund of "Iran and Asia Studies" (IRAS) noticed that Russian-Iranian relations acquired a "strategic appearance" when Russia seriously and effectively began to act on the Syrian scene as a force to counter terrorism. Already then, taking into account the interests of both countries', relations of partnership in the sphere of defense and military sphere began to be formed (Khorasan, 2017).

First of all, the common perception of a Western challenge to their national identities is one of the bases of their partnership (Therme, 2018). The current Russia-Iran partnership in Syria is typically based on their mutual antagonism towards the influence of the United States as well as the Sunni radicalism in Syria (Rubin, 2016). Their mutual goals to reduce and counter against U.S. influence in Syria contribute to a temporary partnership between them. And the partnership may continue as long as countering the influence and hegemonic ambition of the U.S. and its allies in the Middle East has been their common objective.

Secondly, Russia and Iran has involved a high degree of military-security cooperation, especially in Russia's steady and sustained supply or sale of sophisticated military hardware to Iran. The willingness to sell frontline weapons has been "the hallmark of strategic relations between (the suppliers) and their clients". The pattern of arms trade has been the strategic component of relations and "the quantum of the arms trade" defines the relations among major powers (Kumaraswamy, 2020: pp. 59-60). The reason lies in that Tehran and Moscow share a "communality of geopolitical interests" (Mamedova, 2009). Russia has been strived to promote stability on its southern borders where the collapse of the Soviet Union has caused the vacuum of power. Russians appreciate that Tehran did not criticize Moscow's military campaigns in Chechnya and backed Russia's observer status in the Organization of the Islamic Conference (now the Organization of Islamic Cooperation) (Trenin, 2016). In spite of mutual distrust and conflict, Russia and Iran have similar geopolitical pressures from the West. Russia fears western incursion in Caucasus and Central Asia, and Iran has adopted the "Policy of Looking East" to develop strategic relations with Russia and China since 2007. The US regional presence is a direct security threat to both Moscow and Tehran. "(R)estricting Western access to their zones of influ- 
ence in the Caucasus, Central Asia, Afghanistan, Iraq and Persian Gulf" is similar to their national interest. Due to their common interests, Russo-Iranian cooperation is specifically "flourishing in the area of military hardware and nuclear technology" (Asisian, 2013).

Thirdly, both countries have economic motivations for their interventions in support of Assad. Syria is in the key geographic area for the pipelines transiting gases from Caspian Sea to European Market. Confronting the economic sanctions by the US and its allies, both need to enhance their economic relations. Cooperation with Eurasian Economic Union (EAEU) could provide Iran with an opportunity to "mitigate the effects of the U.S. sanctions". That several EAEU countries are also under the Western sanctions will certainly help Iran in countering these sanctions. In 2020, Russia accounts for approximately $75 \%$ of all trade between the EAEU and Iran. In other words, the interim EAEU-Iran FTA has mainly fostered the trade between Russia and Iran. The "rapprochement with the EAEU" could help Iran "to break out of its political isolation" and bolster its ties with Eurasian countries (Smagin, 2021).

Finally, Syria is of great importance for both Russia and Iran. They both are concerned about the growth of Salafi and Wahhabi movements in Syria (Milani, 2013). The consolidation of the Syrian Assad regime is one of their common policy goals. Both Russia and Iran attempt to stabilize the situation in Syria and dominate the regional order. The necessity to share each other's potential interests unites both countries. The Syrian crisis for the first time in history created conditions under which Russia and Iran became parts of a joint coalition. In this regard, Iran for the first time since the revolution of 1979 allowed foreign state (Russia) to use its territory (Shahroki Airbase or Noje Aibaise) for military operations in the third country (Syria) (Trenin, 2016). This fact demonstrates a unique step for Iran, as it has always opposed the presence of any foreign forces on his territory (Karami, 2016).

From Iran's point of view, there are several reasons for cooperation with Russia. The historical experience of Iran demonstrates that the achievement of the objectives in the political sphere facilitated by actions within the framework of coalitions. The larger, more complex and deeper coalition, the more opportunities for Iran to achieve political goals. Presence of the coalitions in the Syrian crisis settlement also facilitates the achievement of Iran's goals (Moradi, 2016). Cooperation with Russia as a superpower with veto power in the United Nations is a rational practice and is important for Iran, especially in the framework of the Syrian crisis. Moreover, Moscow is pursuing an independent from the West policy in resolving situation in Syria, what also needs the support from Iran.

From Russia's point of view, the Assad regime is its traditional ally. Iran's regional influence in Iraq and Syria, Iran's full support for Bashar Al-Assad's government, countering terrorism and radicalism in Syria are factors that encourage Russia to develop cooperation with Iran. Specifically, Iran is necessary in Syria to fulfill the tasks of Russian policy, as Iran plays a key role on the ground space in Syria. The success of Damascus and Moscow military actions directly depends 
on the permanent presence of the Iranian Missile Defense Forces. For example, in the Northern Hama on the contact line with opposition there were units of the Iraqi "Harakat al-Nujba" and "Imam Ali Battalion", the Lebanese "Hezbollah", the Syrian-Lebanese "Liwa al Baaqer", the Syrian-Iranian "Al Mukhtar al Thaqafi Brigade", and the units of "National Defense Forces", which were formed in the image of the Iranian paramilitary militia "Basij" (Mardasov \& Kojanov, 2017).

Thus, Russian-Iranian cooperation is carried out in two directions. One is the military and operational cooperation, the other is political and diplomatic cooperation. In the military sphere, a chain of Russia, Iran and the Syrian government's joint actions were implemented to oust terrorists or limit their capabilities, as well as to stabilize power in the liberated regions. In the political and diplomatic spheres, attempts were also made to establish a ceasefire and provide negotiations on the future of Syria, which did not receive significant support from all the other international parties of the conflict because of the deep differences between them (Vahid, 2017).

However, the benefits from these converging interests do not constrain or compensate for the disadvantages in respect of their diverging goals.

\section{The Diverging Goals of Russia and Iran in Syria and Beyond}

In October 2018, the then Deputy Foreign Minister of Iran, Hossein Jaber Ansari noted that Iran has not concluded a strategic alliance with Russia, but has established relations that are based on mutual interests (including Syria). He stressed the special role of Moscow for Tehran as a "big neighbor and world power" and "no political force in Iran can ignore the fact that Russia is our strong neighbor" (Ansari, 2018). In the Syrian settlement, Russia and Iran closely cooperate both in the active phase of conflict and in the negotiation process especially in the Astana peace process. Both Russia and Iran attempt to shift "the Syrian peace process from Assad's ouster to humanitarian issues and the cessation of violence". Guaranteeing the "territorial integrity of Syria" and "lessening the potential for conflict" in Syria serve the national interest of both (Cengiz, 2020). However, their diverging goals prevent the promotion of their relations to a stable strategic level even if they are close military allies in Syria.

Firstly, despite that Russia and Iran have a common understanding of the world and regional processes, they have serious ideological differences. After the collapse of the USSR, Russia is still in search of its national identity and national idea, but it is a completely secular state. In contrast with Russia, after 1979 revolution, Iran embarked on the path of building a theocratic pan-Islamist state according to Islamic doctrine. Iran's diplomatic embracing of Russia seems to have been rooted in its desire to "protect Khomeinism in matters of foreign policy" (Therme, 2018). Meanwhile, "Moscow has been careful to stay away from sectarian strife in the Middle East." As a close partner with the Shiite regimes, Russia 
has kept intensive contacts with the Sunnis especially the Saudis and the Turks (Trenin, 2015). Considering that ideology often determines the goals and objectives of Iranian foreign policy, the ideological differences that are too difficult to transcend are the fundamental barriers to their durable partnership.

Secondly, numerous academic articles place emphasis on the instrumentality of Syria in Russia's strategy of redefining its role as a global actor and an essential dialogue partner of the western countries in global and regional security governance (Averre \& Davies, 2015; Pieper, 2019; Trenin, 2015). At the beginning of the Syrian domestic upheavals, on the political level, Russia adheres to the position of non-interference in the internal Syrian conflict and firmly supported the right of Syrians to decide their own fate. But as the situation changed, Russia saw an opportunity to reassert its influence in the Middle East, especially as the official Syrian government invited Russia to provide military aid in the fight against the "terrorists". Thus, Russia is actively acting as a mediator for the conflict settlement: Moscow is calling on the participants of the Syrian conflict to dialogue in order to find a peaceful way out of the crisis, which is an effective way to boost Russian prestige in the Middle East.

Russia's intervention in Syria also illustrates Moscow's willingness to assert its status as an influential great power and discussant over the global or regional order in the future (Krickovic \& Weber, 2018). Thus, strong partnership with Iran is valuable for Russia's ambition to reconfirm its power status on rivalry with the United States. However, just as the character of instrumentality of Syria, Russian foreign policy to Iran is of the same kind of pragmatism. From Russian perspective, its relations with Iran remain secondary to its global strategy or Moscow-Washington relations. For example, Russia would not sacrifice its fame as a responsible world power in terms of limiting Iran's nuclear program. The majority of Iranian political analysts are skeptical and not in favor of a partnership with Russia. They believe "Russia is an unreliable ally that could significantly impair Iran's interests" (Asisian, 2013). Some of them (in particular, the left party in Parliament) support the course of Iranian cooperation with European countries, not with Russia. In other words, Moscow and Tehran pursue very different objectives in the wider Middle East and beyond (Trenin, 2016). Iran has been aspiring to extend its Shiite influence and build a "Shiite arc of influence" from Iran across Iraq and the Levant, while Russia has been emphasizing "its right to co-equality with the Americans in fighting terrorism and managing regional security in the Middle East" (Trenin, 2015). Hezbollah, a key facilitator for Iran's ties with Palestinian Islamic Jihad and other similar Arab groups, is an essential pillar of Iran's deterrence posture towards Israel and the US (Tabatabai, Martini, \& Wasser, 2019). In the eyes of Moscow, Hezbollah is a sectarian politico-military group sometimes conducting violent activities about which Moscow has reservations (Trenin, 2016).

Thirdly, there is a hidden rivalry for influence between Russia and Iran be${ }^{1}$ Sunni calls the Iranian goal for strengthening its positions in the region as "Shiite Crescent", while Iran names it as "Axis of Resistance". 
cause both want to be the dominant external player in Syria. The Syrian conflict has transformed Syria from a "shadow state" dominated by the security apparatus into a "transactional state" dominated by the different regime-aligned profiteers (Khatib \& Sinjab, 2018). Russia is "seeking to reshape Syrian institutions to guarantee long-lasting loyalty to Moscow' according to its own interests, while "Iran is implanting influence both through Syrian state institutions and from outside them". Russia is trying to hold the "upper hand in its relationship with Syria" and bounding "Syria closely to Moscow's agenda" (Khatib \& Sinjab, 2018). Iran has been aspiring to extend its Shiite influence and build a "Shiite arc of influence" from Iran across Iraq and the Levant. The Assad regime has been recognized as the essential part of Iran's "Shiite arc of influence". Iran intervened in 2013 and since then it has been actively working with the militia and local groups representing the branches of the Lebanese Hezbollah (The National Ideological Resistance in Syria) and Iraqi Hezbollah (Syrian "Islamic Resistance" groups), as well as with units of the Local Defense Forces in Aleppo and the National Defense Forces (NDF), consisting of Alawites, local Sunnis and other Syrians. All those militia and groups are under the control of Islamic Revolutionary Guard Corps (IRGC) advisers and partially or fully funded by Iran. So, Tehran not only attracted foreign Shiite groups to Syria, but also endeavored to organize local paramilitary groups that are loyal to Tehran's authority. In fact, those groups are "parallel army" that provides Iran with a long-term presence in Syria, which causes even in Damascus' cautions (Mardasov \& Kojanov, 2017).

Tehran and Moscow may disagree with each other on the post-conflict settlement of Syria. Iran prefers the settling of Shiite in areas where Sunnis and others have been removed, which is called Shiaization or Shiitization in Syria by many people. But Russia prefers the return of the Sunnis (Therme, 2018: p. 560). Though Russia relies on Iran in the negotiation process and post-conflict settlement, the Russian leadership is not ready to fully and unconditionally support Iran. Russia coordinates its actions in Syria with the US, does not stop consultations with Israel and negotiating with Saudi Arabia. Russia is trying to be a mediator in the negotiation process in Syria: it takes part in the Geneva process, simultaneously launches the negotiation mechanism in Astana and raises the status of Iran and Turkey as guarantors of the ceasefire in Syria (Websiteh \& Lapenko, 2017). However, Iran was not present at the negotiations in Istanbul in October 2018. This is an indication that Russia is striving to achieve maximum success, so it did not promote Iran's inclusion in this format of negotiations, because Iran adheres to a more radical position and would not have contributed constructively to the negotiations.

Russia's intervention not only greatly increased the prospect of the survival of Assad regime, but also tilted the balance of power in favor of Damascus in the conflict. Yet "Russia gains do not translate in a one-to-one ratio as gains for Iran". On the contrary, Russian gains may "partly come as the expense of Iranian influence with the Assad regime". Iran's vision of a Syria government with 
the NDF and the other pro-Iranian actors' maintaining high level of autonomy is probably to "clash with Russia's preference for a stronger central government" (Juneau, 2020). Moreover, Iran is uncomfortable with Moscow's growing ties with Syrian Kurds and keeping the settlement of Syrian political process open to almost all actors, especially, the US, Israel, Saudi Arabia.

Fourthly, Iran and Russia are divergent on Israel. Iran sees Israel as an enemy or a main rival in Middle East, but Russia always maintains diplomatic relations with Israel. While planning its actions in Syria, Russia has been trying to take into account Israel's interests. However, this is extremely difficult for Iran. For example, following the requests of Tel-Aviv, Russia had to if not to put an end to the presence of Iranian militants in Syria, then at least to achieve their withdrawal from the territories controlled by Israel. In summer 2017, Moscow began to discuss the question of creating de-escalation zones in the South of Syria. This discussion was separated from Astana format: it excluded the participation of Iran and Turkey, but included Israel, Jordan and the US (this format was called "Amman consultations"). Formally, Iran supported these agreements that reached on the creation of armistice zones near the borders with Israel, but it noted that the practice of separate agreements could "undermine the sovereignty and territorial integrity" of Syria. Undoubtedly, "Amman consultations" calls Tehran's concern because of potential possibility that this platform could gradually replace the Astana process (Tasnim News Agency, 2017). The further negotiation process will depend on Iran's military presence in Syria. Currently this is the most irritating factor for Israel, the US and the European States. Israel has repeatedly expressed concern about the Iranian military presence in Syria, sometimes very aggressively by striking at alleged Iranian targets. The US also called about the need to liberate Syria not so much from terrorist groups as from Iranian forces.

Finally, despite that the interim agreement signed by EAEU and Iran entered into force in October 2019, there are some difficulties in "replacing the interim agreement with a permanent one". A serious obstacle to the economic cooperation between EAEU and Iran is "the EAEU's ongoing FTA negotiations with Israel" (Smagin, 2021). As a country relying on the export of natural gas, Russia is aware of the significance of Syria's location as a route to Europe (Cengiz, 2020). Russia's economic motivation of its intervention in Syria aims at integrating a regional energy network and keeping Russia's regional energy dominance within the network. It will provide Russia with influence to oversight the energy supply to the European market. Therefore, Russia backs the proposed construction of an Islamic Pipeline called the Iran-Iraq-Syria Friendship Pipeline from the Iranian Pars gas fields through Iraq, across Syria, and to the Mediterranean and Lebanon, which will be in competition with the US-backed Qatari Pipeline (Maher \& Pieper, 2021). Iran may be willing to be a close partner with Russia to check and challenge the US and Israel's influence in the Middle East. But Iran has its own security concerns and is also a key supplier of energy to the 
European market. Holding the world's second largest proved gas reserve, Iran is a Russian competitor in the future energy market (Sinjab, 2018). And probably they will compete for primacy in the Islamic Pipeline.

Moreover, the backbone of the economies of both Iran and Russia is their oil and gas sector. So the EAEU cannot offer Iran anything that China could offer. And with the dominant position of Russia on the EAEU energy markets, Iran cannot significantly increase its energy supplies to EAEU market without Russia's consent (Smagin, 2021). With both countries being oil and gas exporters and sharing a number of energy-consuming markets, "Iran could eventually become Russia's main rival in gas exports” (Therme, 2018).

\section{Conclusion}

Historically, Russia and Iran had been rivals or even enemies for over 500 years. They had diverging national goals and distrustful relations. Warm water ports and influences in South Asia and the Middle East have been the two objectives of Russian foreign policy, but Iran or Persia has been a check or a barrier for these Russian objectives (Henley-Putnam School of Strategic Security, 2021). Today, Moscow and Tehran, in fact, are the conductors of each other's interests in Syria, so the demonstration of rapprochement is the factor that in the current geopolitical and economic realities, both sides will take what they need for their own purposes. Both Moscow and Tehran are interested in achieving early peace on Syrian territory while maintaining their long-term military presence. Russia has created a legal and material basis for the Russian military bases in Syria. Iran has also signed an agreement on military and technical cooperation, which enshrines the Iranian presence in Syria for a long time. As long as "relations between Tehran and Washington remain hostile", and as long as "Moscow and Tehran can find common grounds for cooperation" in Syria (Tarock, 1997: p. 221), their present rapprochement will remain.

But strategic partnerships are "primarily goal-driven rather than threat-driven arrangements" (Wilkins, 2008: p. 361). And their conflicting national interests will root their present rapprochement in distrust and suspicion in the future, if Iran continues to pursue its religious and geo-political hegemony in the region (Henley-Putnam School of Strategic Security, 2021). Their relations are not a comprehensive strategic partnership yet (although in the rhetoric of statesmen sometimes it's called "strategic partnership"), but mutually beneficial cooperation and tactical partnership. To put it exactly, the relationship is a kind of Russia-Iran rapprochement. Just as the words of the Secretary of the Iranian Security Council Ali Shamkhani:

"Of course, it is possible that sometimes our goals may not coincide in some areas-such as the fight against the Zionist regime. Here the interaction takes a different form. But each country is independent, and each state builds its foreign policy based on its own national interests. The policy of the Islamic Republic of Iran from the very first year of the revolution (Is- 
lamic revolution 1979) was also based on the principles of independence and lack of attachment to the policies of any superpower. It should be noted that cooperation is not a renunciation from independence, but it is an existence of common goals that can be achieved only by joint efforts" (Khorasan, 2017).

\section{Acknowledgements}

Preparatory research for this article is supported by Shanghai University of Political Science and Law "2020 Research Project” (No. 2020XJ06).

\section{Conflicts of Interest}

The authors declare no conflicts of interest regarding the publication of this paper.

\section{References}

Asisian, N. (2013, November 23). Russia \& Iran: Strategic Alliance or Marriage of Convenience. Small Wars Journal.

https://www.researchgate.net/publication/281903441_Russia_Iran Strategic Alliance or Marriage of Convenience

Ansari, H. (2018, October 22). Iran and Russia Have Established a Strategic Partnership in Syria. EurAsia Daily.

https://eadaily.com/ru/news/2018/10/22/ansari-iran-i-rossiya-ustanovi-strategicheskoe -partnerstvo-v-sirii

Averre, D., \& Davies, L. (2015). Russia, Humanitarian Intervention and the Responsibility to Protect: The Case of Syria, International Affairs, 91, 813-834. https://doi.org/10.1111/1468-2346.12343

Cengiz, S. (2020). Assessing the Astana Peace Process for Syria: Actors, Approaches, and Differences. Contemporary Review of the Middle East, 7, 200-214. https://doi.org/10.1177/2347798920901876

Czechowska, L. (2013). The Concept of Strategic Partnership as an Input in the Modern Alliance Theory. The Copernicus Journal of Political Studies, No. 2, 36-51.

Czechowska, L., Tyushka, A., Domachowska, A., Gawron-Tabor, K., \& PiechowiakLamparska, J. (Eds.) (2019). States, International Organizations and Strategic Partnerships. Cheltenham, UK: Edward Elgar Publishing Limited.

Henley-Putnam School of Strategic Security, National American University (2021). Russia-Iran: A Strategic Alliance of Enemies. https://henley-putnam.national.edu/article/russia-iran-alliance-of-enemies/

Holslag, J. (2011). The Elusive Axis: Assessing the EU-China Strategic Partnership. Journal of Common Market Studies, 49, 293-313. https://doi.org/10.1111/j.1468-5965.2010.02121.x

Juneau, T. (2020). Iran's Costly Intervention in Syria: A Pyrrhic Victory. Mediterranean Politics, 25, 26-44. https://doi.org/10.1080/13629395.2018.1479362

Khatib, L., \& Sinjab, L. (2018, October 10). Syria's Transactional State: How the Conflict Changed the Syrian State's Exercise of Power. Chatham House. https://www.chathamhouse.org/2018/10/syrias-transactional-state

Karami, A. (2016, August 17). Iran Officials Defend Russian Use of Hamadan Air Base. 
Al-Monitor.

https://www.al-monitor.com/pulse/tr/contents/articles/originals/2016/08/iran-russia-s yria-hamadan-airbase-fighter-jets.html

Khorasan (Iran) (2017, June 17). Strategic Partnership of Iran and Russia (Interview). Russia Now.

https://russia-now.com/228711/khorasan-\%D0\%B8\%D1\%80\%D0\%B0\%D0\%BD-\%D1 \%81\%D1\%82\%D1\%80\%D0\%B0\%D1\%82\%D0\%B5\%D0\%B3\%D0\%B8\%D1\%87\%D0\%B 5\%D1\%81\%D0\%BA\%D0\%BE\%D0\%B5-\%D0\%BF\%D0\%B0\%D1\%80\%D1\%82\%D0\%B D\%D0\%B5\%D1\%80\%D1\%81\%D1\%82\%D0\%B2\%D0\%BE-\%D0\%B8/

Krickovic, A., \& Weber, Y. (2018). Commitment Issues: The Syrian and Ukraine Crisis as Bargaining Failures of the Post-Cold War International Order. Problems of PostCommunism, 65, 373-384. https://doi.org/10.1080/10758216.2017.1330660

Kumaraswamy, P. R. (2020). Redefining "Strategic" Cooperation. In J. Prasad, S. Rajiv, \& C. Samuel (Eds.), India and Israel: The Making of a Strategic Partnership (pp. 56-60). Routledge.

Lavrov, S. (2015, August 17). Foreign Minister Sergey Lavrov's Statement and Answers to Media Questions at a Joint News Conference Following Talks with Iranian Foreign Minister Mohammad Javad Zarif, Moscow. August 17, 2015.

https://www.mid.ru/en/web/guest/adernoe-nerasprostranenie/-/asset publisher/JrcRGi $\underline{5 \mathrm{UdnBO} / \text { content/id/1654185 }}$

Maher, D., \& Pieper, M. (2021). Russian Intervention in Syria: Exploring the Nexus between Regime Consolidation and Energy Transnationalisation. Political Studies, 69, 944-964. https://doi.org/10.1177/0032321720934637

Mamedova, N. (2009, December 3). A Communality of Geopolitical Interests. Bitterlemons-International, 7 .

http://www.bitterlemons-international.org/previous.php?opt=1\&id=297\#1210

Mardasov, A., \& Kojanov, N. (2017, September 14). Russian-Iranian Cooperation in Syria: Limited Does Not Mean Complete. Russian International Affairs Council. https://russiancouncil.ru/analytics-and-comments/analytics/rossiysko-iranskoe-vzaimo deystvie-v-sirii-ogranichennoe-ne-znachit-zakonchennoe/

Milani, M. (2013). Why Tehran Won't Abandon “Assad(ism)”. Washington Quarterly, 36, 79-93. https://doi.org/10.1080/0163660X.2013.861715

Moradi, A. (2016). The Syrian Crisis and National Security of Iran. Strategic Policy Studies, $28,125-152$.

http://ensani.ir/fa/article/365772/\%D8\%A8\%D8\%AD\%D8\%B1\%D8\%A7\%D9\%86-\%D 8\%B3\%D9\%88\%D8\%B1\%DB\%8C\%D9\%87-\%D9\%88-\%D8\%A7\%D9\%85\%D9\%86\%D B\%8C\%D8\%AA-\%D9\%85\%D9\%86\%D8\%B7\%D9\%82\%D9\%87-\%D8\%A7\%DB\%8C-\% D8\%AC\%D9\%85\%D9\%87\%D9\%88\%D8\%B1\%DB\%8C-\%D8\%A7\%D8\%B3\%D9\%84\% D8\%A7\%D9\%85\%DB\%8C-\%D8\%A7\%DB\%8C\%D8\%B1\%D8\%A7\%D9\%86

Nadkarni, V. (2010). Strategic Partnerships in Asia: Balancing without Alliances. Routledge. https://doi.org/10.4324/9780203865019

Pieper, M. (2019). "Rising Power” Status and the Evolution of International Order: Conceptualising Russia’s Syria Policies, Europe-Asia Studies, 71, 365-387.

https://doi.org/10.1080/09668136.2019.1575950

Rubin, M. (2016, July 1). Iran-Russia Relations. American Enterprise Institute. https://www.aei.org/publication/iran-russia-relations

Sinjab, L. (2018, February). Russia and Iran Are Increasingly Competitive in Syria. Chatham House.

https://syria.chathamhouse.org/research/russia-and-iran-are-increasingly-competitive- 
in-syria

Smagin, N. (2021, April 27). EAEU-Iran Trade and Its Prospects. Modern Policy. https://www.bilaterals.org/?eaeu-iran-trade-and-its-prospects\&lang=en

Tabatabai, A., Martini, J. \& Wasser, B. (2019, September). The Iran Threat Network (ITN): Four Models of Iran's Nonstate Client Partnerships, RAND Corporation. https://www.rand.org/pubs/research reports/RR4231.html

Tarock, A. (1997). Iran and Russia in "Strategic Alliance". Third World Quarterly, 18, 207-224. https://doi.org/10.1080/01436599714911

Tasnim News Agency (2017, July 15). Iran's Top Security Official, Russian Envoy Discuss Syrian Crisis. Tasnim News Agency.

https://www.tasnimnews.com/en/news/2017/07/15/1465159/iran-s-top-security-official -russian-envoy-discuss-syrian-crisis

Therme, C. (2018). Iran and Russia in the Middle East: Toward a Regional Alliance? Middle East Journal, 72, 449-562. https://doi.org/10.3751/72.4.11

Trenin, D. (2015, October 13). Putin's Syria Gambit Aims at Something Bigger than Syria. Carnegie Moscow Center.

https://carnegiemoscow.org/2015/10/13/putin-s-syria-gambit-aims-at-something-bigge r-than-syria/ij $2 \mathrm{j}$

Trenin, D. (2016, August 18). Russia and Iran: Historic Mistrust and Contemporary Partnership. Carnegie Moscow Center.

https://carnegiemoscow.org/2016/08/18/russia-and-iran-historic-mistrust-and-contem porary-partnership-pub-64365

Vahid, H. (2017). Russian-Iranian Relations in the Framework of the Settlement the Syrian Crisis. Political Science, No. 7, 187-190.

https://cyberleninka.ru/article/n/rossiysko-iranskie-otnosheniya-v-ramkah-uregulirova niya-siriyskogo-krizisa/viewer

Websiteh, A., \& Lapenko, M. V. (2017). The Syrian Conflict Settlement within the Framework of the Negotiation Process in Astana. Modern Eurasian Studies, 3, 24-37.

https://www.academia.edu/41661713/\%D0\%A1\%D0\%98\%D0\%A0\%D0\%98\%D0\%99\% D0\%A1\%D0\%9A\%D0\%9E\%D0\%95 \%D0\%A3\%D0\%A0\%D0\%95\%D0\%93\%D0\%A3\% D0\%9B\%D0\%98\%D0\%A0\%D0\%9E\%D0\%92\%D0\%90\%D0\%9D\%D0\%98\%D0\%95 \% D0\%92 \%D0\%A0\%D0\%90\%D0\%9C\%D0\%9A\%D0\%90\%D0\%A5 \%D0\%9F\%D0\%95\% D0\%A0\%D0\%95\%D0\%93\%D0\%9E\%D0\%92\%D0\%9E\%D0\%A0\%D0\%9D\%D0\%9E\%D 0\%93\%D0\%9E \%D0\%9F\%D0\%A0\%D0\%9E\%D0\%A6\%D0\%95\%D0\%A1\%D0\%A1\%D 0\%90\%D0\%92

Wilkins, T. S. (2008). Russo-Chinese Strategic Partnership: A new Form of Security Cooperation? Contemporary Security Policy, 29, 358-383.

https://doi.org/10.1080/13523260802284365 